\title{
COMMISSION 36: THE THEORY OF STELLAR ATMOSPHERES (LA THÉORIE DES ATMOSPHËRES STELLAIRES)
}

\section{Report of Meetings}

President: R. N. Thomas.

1. One business meeting of the Commission was held:

The following officers were elected:

President: R. Cayrel.

Vice-President: D. Mihalas.

Organizing Committee: E. Avrett, K. Hunger, V. L. Khoklova, J. Hutchings, B. E. J. Pagel, M. Vardya and R. N. Thomas.

In addition, it was agreed that the President might co-opt one or two additional members of the Organizing Committee, one of which might be the Secretary of the Commission. (This has been done by Cayrel. F. Praderie has been co-opted as Secretary to the Organizing Committee; S. Rucinski has been co-opted as Commission member.)

2. A full-day symposium on the Next Decade of Research in Stellar and Solar Atmospheres was held. The four invited speakers were:

L. Kuhi: Stellar Observational Work.

P. Delache: Stellar Theory.

J. Beckers: Solar Observational Work.

H. Rosenberg and M. Kuperus: Solar Theory.

The rest of the day was devoted to informal discussion.

The entire symposium was tape-recorded; it is currently under debate what to do with the tapes. This was jointly organized by Commissions 10,12 and 36 .

3. A full-day symposium on Waves in Stellar and Solar Atmospheres was held. The two invited speakers were:

J. Leibacher: Wave-Generation.

P. Souffrin: Wave Propagation and Dissipation.

The rest of the day was devoted to informal discussion. The symposium was not tape-recorded. Jointly organized by Commissions 12 and 36 .

4. A half-day symposium was held on Ap Stars, jointly organized by Commissions 29 and 36 (see the Report of Commission 29).

5. Commission 36 went firmly on record against publishing a bibliography of the work of the Commission in terms of reference numbers, it wishes title and author. Commission 36 makes no suggested changes in its rules over what presently exists. 